\title{
Distribution and diversity of littoral macroinvertebrates within extensive reed beds of a lowland pond
}

\author{
Jan Sychra $^{1 *}$, Zdeněk Adámek $^{2}$ and Karla Petřivalská ${ }^{1}$ \\ 1 Department of Botany and Zoology, Faculty of Science, Masaryk University, Kotlářská 2, 61137 Brno, Czech Republic \\ ${ }^{2}$ University of South Bohemia in České Budějovice, Faculty of Fisheries and Protection of Waters, South Bohemian Research Center \\ of Aquaculture and Biodiversity of Hydrocenoses, Zátiši 728/II, 38925 Vodňany, Czech Republic
}

Received 12 January 2010; Accepted 28 August 2010

\begin{abstract}
Although habitats of hard emergent macrophyte beds, including reed beds (Phragmites australis), are very common in the littoral zones of stagnant waters in central Europe, research investigating their macroinvertebrate communities is still lacking. In this study, the spatial distribution of macroinvertebrates was studied within large reed beds in the littoral zone of a lowland fishpond (Nesyt, SE Moravia, Czech Republic). Using a hand net, horizontal line transects in the reed bed leading from the marginal area with the open water towards the shore were sampled. The results of NMDS ordination and PERMANOVA test proved that the taxonomic composition of the macroinvertebrate assemblage changed significantly along the investigated horizontal transect from the open water towards the shore, together with gradual changes in some environmental factors. The taxa diversity was found to be the highest in the areas closest to the shore. In the reed bed areas near open water, corixids, aquatic insects larvae, leeches, water mites, some naidids and tubificids, which represented free-swimming invertebrates with tracheal gill breathing, ectoparasites, gatherers/collectors and taxa preferring pelal and inorganic substrates, were more abundant compared with the interiors of reed beds. On the other side, in the shallow dense interior of reed beds close to the shore, gastropods, water slaters, some naidids and enchytraeids, aquatic beetles and dipteran larvae were characteristic taxa, which belonged especially to grazers and scrapers, shredders and invertebrates preferring phytal and POM (particulate organic matter) microhabitats. Different predators were recorded in areas near open water and near the shore. This invertebrate spatial distribution probably reflects changes in microhabitat and environmental conditions along the investigated horizontal transect. The results of this study proved that extensive reed beds serve as refuges for many groups of aquatic macroinvertebrates within lowland fishpond ecosystems.
\end{abstract}

Key words: Invertebrates / macrophytes / spatial distribution / functional groups / wetlands

\section{Introduction}

Aquatic macrophytes, both submerged and emergent, are a very important part of the aquatic environment. Apart from their assimilatory function, they play an unfungible role in aquatic food chains and in creating and diversifying habitats for many aquatic organisms (Bazzanti et al., 2009). Plant beds covering the littoral zone of ponds and lakes create ecotones, which frequently prove to have biodiversity higher than in adjacent terrestrial and aquatic habitats (Pieczyńska, 1972; Dvořák and Imhof, 1998; Petr, 2000; Zbikowski and Kobak, 2007). Reed beds (Phragmites australis, (Cav.) Steud.) are a common type of vegetation in the littoral zones of stagnant waters in central Europe. Research on the structure and functioning of reed beds in fishpond littorals is a subject of

\footnotetext{
*Corresponding author: dubovec@seznam.cz
}

a number of studies (Dykyjová and Květ, 1978; Ritterbusch, 2007). In terms of their spatial distribution, two forms of reed beds may be distinguished: the erosion form, developed along wind-exposed and steep shores, and the accumulation form, which is common in shallow and wind-sheltered lagoons (Hejný, 1971). In these latter habitats, reed beds can be quite extensive and dense and provide specific environmental conditions (e.g. reducing sun illumination and dissolved oxygen levels, increasing organic matter accumulation, etc.). Because of the strong dominance of the reed, these communities are usually very poor in plant species (Hejný and Husák, 1978). Moreover, dense reed beds are not accessible to fish, which downgrades the fish farming capacity of a fishpond (Ritterbusch, 2007). These facts can affect the diversity and horizontal distribution of aquatic macroinvertebrates there (Dvořák and Imhof, 1998; Jayawardana et al., 2006). 
The abundance and distribution of aquatic macroinvertebrates in the littoral zones are mostly related to habitat conditions, such as substrate type, macrophyte biomass, amount of organic detritus and other environmental factors (Cyr and Downing, 1988; Dvořák and Imhof, 1998; Weatherhead and James, 2001). Aquatic macrophytes are colonized by invertebrates as a life substrate, for direct feeding, for periphyton grazing (Soszka, 1975) or as a protection against foraging by fish (Petr, 2000). Changing environmental conditions inside the reed beds are in connection with local changes in both abiotic and biotic parameters in particular mesohabitats (Ondok, 1978; Úlehlová and Přibil, 1978) and can largely influence the macroinvertebrate community distribution (e.g. Dvořák and Imhof, 1998). Recently, a horizontal gradient of abiotic and biotic characteristics, which results in changes of the macroinvertebrate assemblage, was found in a lake-vegetated littoral zone in Finland (Tolonen et al., 2001). On the contrary, the distributional pattern of macroinvertebrate communities in fishpond littorals is still not well known. Most of the studies of macroinvertebrates in fishpond ecosystems in central Europe have focused on bottom sediments or submerged plants, while research of hard emergent macrophyte beds and their macroinvertebrate communities is still lacking. This can partly be attributed to methodological difficulties (Kuflikowski, 1970). The aim of this study was to find out whether the taxonomic and functional composition and abundance of aquatic macroinvertebrates varies in extensive reed beds in the littoral zone of a large lowland fishpond along the inner horizontal transect.

\section{Material and methods}

\section{Sampling site}

Research was performed at the Nesyt fishpond, which is situated in the south-eastern part of the Czech Republic at an elevation of $175 \mathrm{~m}$ above sea level. With an area of 315 ha, it is one of the largest fishponds in the country, and is also a part of the Lednice fishponds UNESCO Nature Reserve. The Nesyt fishpond is highly eutrophic with naturally-enhanced conductivity (about $1400 \mu \mathrm{S} . \mathrm{cm}^{-1}$ ) and is exploited for extensive fish farming. During the sampling period, four-year-old carp (Cyprinus carpio L.) were the prevalent fish species. The shoreline is fringed on about $70 \%$ of its perimeter by several types of wetland vegetation, predominantly by extensive and dense reed beds, which can be very wide (up to $30 \mathrm{~m}$ ) in shallow lagoons in the eastern and western parts of the pond (see Fig. 1). For these reasons, this site is very suitable and representative for research on aquatic invertebrate assemblage patterns in lowland pond littoral reed beds.

\section{Sampling design}

The best season for research on most phytophilic macroinvertebrates is obviously during the late summer,

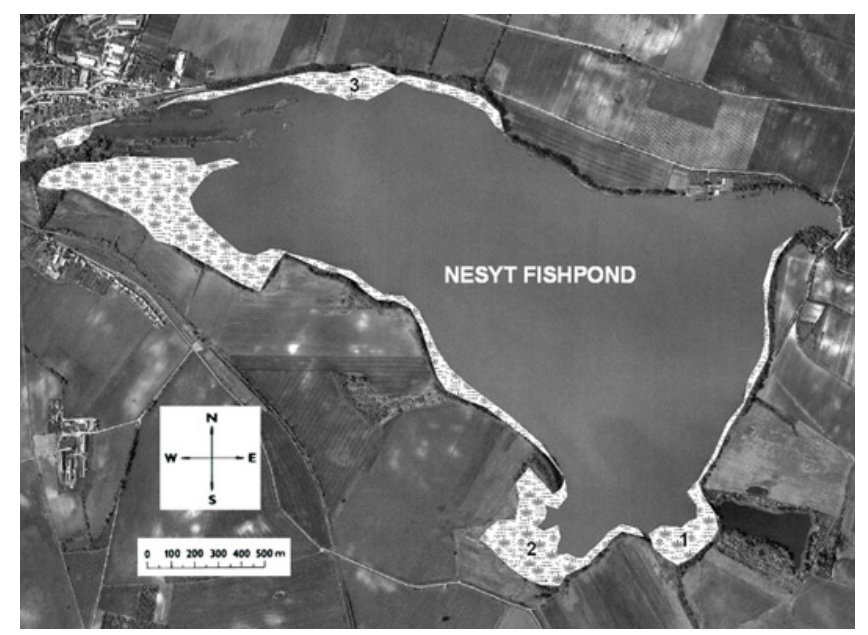

Fig. 1. Three sampling sites at the Nesyt fishpond, where line transects were located in pairs. The main extensive reed beds of the fishpond are indicated.

when the growing season culminates for both animals and plants (Matlak, 1963; Kuflikowski, 1977; Dvořák and Imhof, 1998). Therefore, sampling was performed during the period from August to September 2005.

Hard emergent vegetation, including the reed beds, is quite difficult to sample because of problems involved in cutting hard stems from the substratum and because of the necessity for rapid capture of invertebrates. Of a number of possible sampling methods, hand sweep netting seemed to be a suitable and representative method, which provides good and quick semiquantitative data acquisition for the assessment of aquatic macroinvertebrate diversity and abundance in dense reed beds (O'Connor et al., 2004; García-Criado and Trigal, 2005; Sychra and Adámek, 2010).

Using a hand sweep net, reed beds of the Nesyt fishpond were sampled in six horizontal line transects leading from the marginal area with open water towards the shore. Sampling sites were located by two transects on three different sites with extensive reed beds (Fig. 1). Because of the various widths of the sampled reed beds $(10-30 \mathrm{~m})$, four points were sampled in each line: two near the open water $(\mathrm{OW} 1=$ in the boundary between reed bed and open water; OW $2=1 \mathrm{~m}$ from open water inwards to the reed bed) and two near the shore ( $\mathrm{SH} 1=1 \mathrm{~m}$ from the shore; $\mathrm{SH} 2=$ about $5 \mathrm{~m}$ from the shore inwards to the reed bed). Thus, the total number of samples was 24. At each sampling point within a transect line, the density of reed stems was about 30-60 stems per half square meter along each line and water depth was $30-70 \mathrm{~cm}$ at each first sampling point (closest to open water) and decreased towards the shore.

At each point, sampling by hand net was performed semiquantitatively as one minute of quick hand net sweeping in the water column within the reed stems, carefully avoiding contact with or disturbance of sediments. At each sampling point, basic environmental factors $(\mathrm{pH}$, conductivity, water temperature and oxygen saturation) were 
Table 1. Variation in investigated environmental factors along the horizontal transect towards the shore and the significance of their linear fit into the two-dimensional NMDS plot based on invertebrate lower taxa (sample names according to sampling design).

\begin{tabular}{|c|c|c|c|c|c|c|}
\hline Samples & $\begin{array}{c}\text { Distance from } \\
\text { the open water }(\mathrm{m}) \\
\text { Me (Q25-Q75) }\end{array}$ & $\begin{array}{c}\mathrm{O}_{2} \text { saturation } \\
(\%) \\
\mathrm{Me}(\mathrm{Q} 25-\mathrm{Q} 75)\end{array}$ & $\begin{array}{c}\mathrm{pH} \\
\mathrm{Me}(\mathrm{Q} 25-\mathrm{Q} 75) \\
\end{array}$ & $\begin{array}{l}\text { Conductivity } \\
\left(\mathrm{mS} . \mathrm{cm}^{-1}\right) \\
\mathrm{Me}(\mathrm{Q} 25-\mathrm{Q} 75)\end{array}$ & $\begin{array}{c}\text { Temperature } \\
\left({ }^{\circ} \mathrm{C}\right) \\
\text { Me (Q25-Q75) } \\
\end{array}$ & $\begin{array}{c}\text { Depth } \\
(\mathrm{cm}) \\
\text { Me (Q25-Q75) } \\
\end{array}$ \\
\hline$\overline{\mathrm{OW}} 1$ & $0(0-0)$ & $114.2(102.2-120.8)$ & $7.60(7.40-7.69)$ & $1.39(1.37-1.41)$ & $18.8(14.7-23.4)$ & $52(28-75)$ \\
\hline OW2 & $1(0-0)$ & $103.7(99.6-112.8)$ & $7.48(7.35-7.66)$ & $1.40(1.38-1.41)$ & $19.1(15.0-23.0)$ & $41(22-68)$ \\
\hline $\mathrm{SH} 2$ & $5(3-7)$ & $72.9(58.8-108.8)$ & $7.41(7.27-7.63)$ & $1.41(1.38-1.44)$ & $17.7(14.1-22.5)$ & $29(18-35)$ \\
\hline SH1 & $11(7-15)$ & $46.5(29.2-69.8)$ & $7.39(7.23-7.62)$ & $1.44(1.40-1.50)$ & $16.4(13.8-18.9)$ & $16(13-23)$ \\
\hline$\overline{r^{2}}$ & 0.7705 & 0.2867 & 0.3809 & 0.1741 & 0.2404 & 0.2822 \\
\hline$p$-Value & $0.001 * *$ & $0.033^{*}$ & $0.004^{* *}$ & $0.138 \mathrm{~ns}$ & $0.071 \mathrm{~ns}$ & $0.039^{*}$ \\
\hline
\end{tabular}

$\mathrm{Me}=$ median; Q25-Q75 = lower-upper quartiles; * $p<0.05 ; * * p<0.01 ;$ ns $=$ not significant.

also measured by a multiparameter measurement device (Hach-Lange HQ40D multi).

All samples were preserved in a $4 \%$ formaldehyde solution. In the laboratory, macroinvertebrates were sorted from the samples and determined to the lowest possible taxonomic level. In most cases it was the species or genus level, except for Hydrachnellae and Chironomidae. These latter were determined to three subfamilies (Chironominae, Orthocladiinae and Tanypodinae).

\section{Statistical analysis}

Relations between recorded environmental factors were determined by using the Spearman's rank correlation coefficient $\left(r_{\mathrm{S}}\right)$ followed by the Bonferroni correction (Holm, 1979). Total numbers of individuals and taxa were analyzed for differences among sampling points using the Kruskal-Wallis ANOVA with multiple comparisons of mean ranks for all groups and the Mann-Whitney U Test for pairwise comparisons.

Non-metric Multi-Dimensional Scaling (NMDS; Cox and Cox, 2001) was used to demonstrate changes in taxonomic and functional structure of the macroinvertebrate assemblage along the investigated horizontal transect. NMDS was based on the Bray-Curtis dissimilarity index calculated on $\log (x+1)$ transformed taxa abundances. The "metaMDS" command from the "vegan" library (Oksanen et al., 2010) was used in R to run NMDS. The "metaMDS" wrapper ensures that several random starts are performed until two convergent solutions are found and the principal components rotate the configuration to maximize the variance of points in the first dimension (NMDS1). Most abundant taxa, environmental factors, functional feeding groups and microhabitat preferences were fitted using the command "envfit" from the "vegan" library (Oksanen et al., 2010) into the NMDS diagram using multiple linear regression, in which these were modelled as a function of the position of the samples on the two NMDS axes (NMDS1 and NMDS2). This analysis was performed both on lower taxa (mostly species level) and higher taxa abundances (mostly class/order level).

Permutational multivariate analysis of variance using distance matrices (PERMANOVA; command "adonis" from the "vegan" library; Anderson, 2001; McArdle and Anderson, 2001) was performed to find significant differences in taxonomical structure among the sampling stations followed by the Bonferroni correction (Holm, 1979). Procrustes analysis (PROTEST; Peres-Neto and Jackson, 2001) with 1000 permutations was used to quantify the statistical significance of concordance between ordinations on higher and lower taxa.

Both analyses and graphs were performed in the softwares R (version 2.10.1; R Development Core Team, 2009) and Statistica (version 8.0; StatSoft, Inc., 2008). All results were considered as statistically significant at the level of $p<0.05$.

Assignment to a functional feeding group and microhabitat preference was performed for each taxon using the Asterics software (version 3.1.1., AQEM consortium, 2008).

\section{Results}

The environmental factors investigated in this study varied along the horizontal transect (Table 1). With the distance from the open water zone, $\mathrm{pH}$ and oxygen saturation decreased. On the other hand, conductivity slightly increased along this gradient. However, changes in the values of these factors were only very small and a significant negative correlation was found only between the distance from the open water zone and oxygen saturation $\left(r_{\mathrm{S}}=-0.641 ; p=0.001\right)$.

Littoral macroinvertebrate assemblage was very taxarich at the study site. Altogether, we found 90 lower taxa, even though chironomid larvae were not identified to the species level (Appendix, available online at www. limnology-journal.org). Water bugs (Heteroptera; mainly from family Corixidae), oligochaetes and chironomid larvae were the most numerous invertebrates at the study site.

Total abundance in the samples did not differ significantly along the horizontal transect. However, slightly higher abundance was recorded in the interior of reed beds close to the shore. In samples closest to the shore (SH1), we found significantly higher numbers of macroinvertebrate taxa compared to samples closest to the open water (OW1; Kruskal-Wallis ANOVA, $p=0.02$; Fig. 2). 

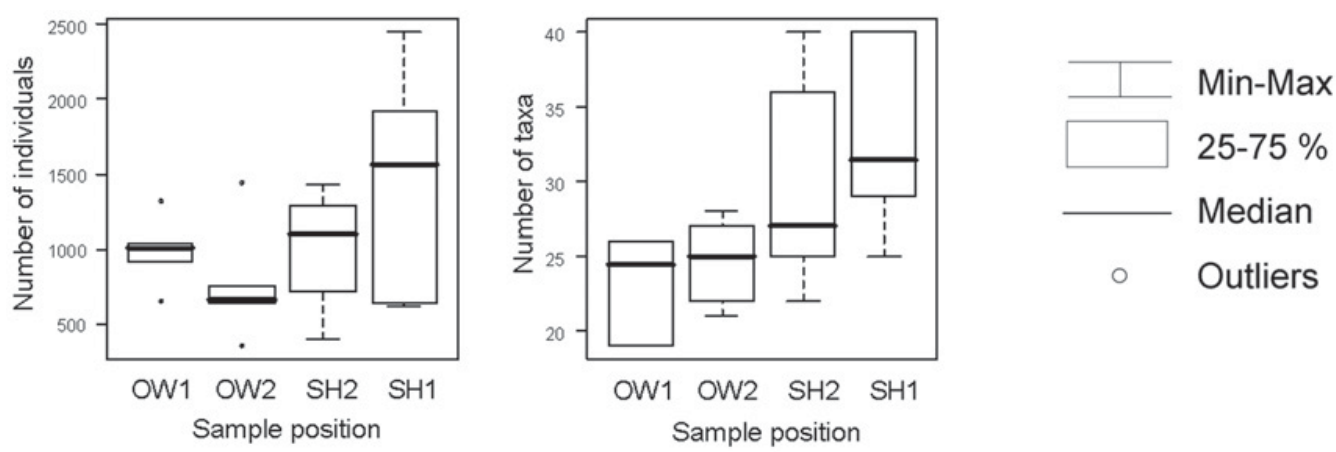

Fig. 2. The results of the Kruskal-Wallis ANOVA on total macroinvertebrate abundance and numbers of taxa along the investigated horizontal transect. From the left to the right are four sampling stations from open water inwards to the reed bed, according to the sampling design.

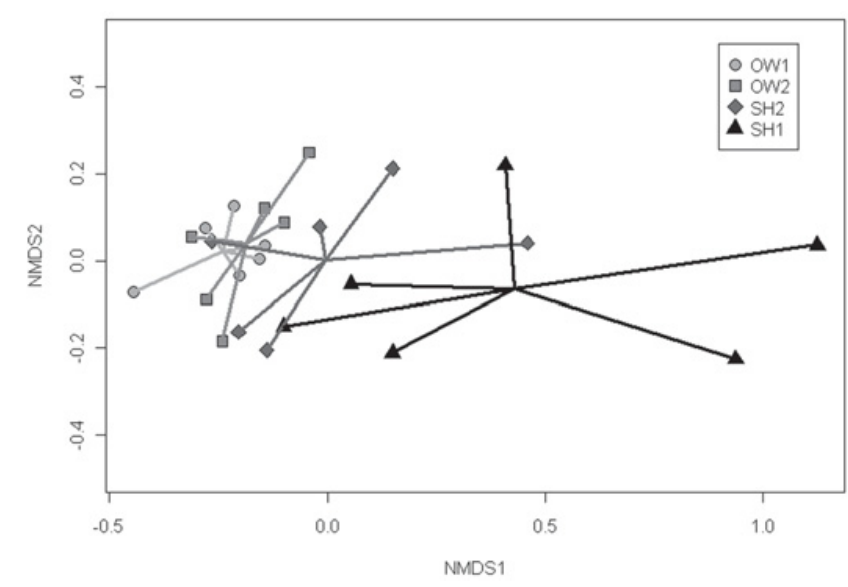

Fig. 3. The NMDS ordination plot in two dimensions performed on lower taxa abundances with samples. Each "spider" represents samples from the same reed bed area in each sampling line $(\mathrm{OW} 1=$ the boundary between reed bed and open water; $\mathrm{OW} 2=1 \mathrm{~m}$ from open water inwards to the reed bed; $\mathrm{SH} 1=1 \mathrm{~m}$ from the shore; $\mathrm{SH} 2=$ about $5 \mathrm{~m}$ from the shore inwards to the reed bed).

Reed bed invertebrate assemblage variation among sampling sites was summarized by NMDS ordination (stress $=0.104$ ). Results of NMDS analysis indicated that the assemblage structure changed from the marginal area of the reed bed towards the shore. Samples close to the open water zone were more homogenous, whereas samples collected deeper in the reed bed (closer to the shore) were rather heterogenous (Fig. 3). The PERMANOVA test confirmed significant differences between assemblages in sample stations OW1 and SH1, and OW2 and SH1 (details in Table 2).

Some abundant taxa were significantly fitted into the NMDS diagram (Appendix), which could be designated as characteristic taxa for some parts of the reed beds (Fig. 4). For the marginal zone between the reed bed and open water, and in first meters inwards to the reed bed, water bugs Sigara sp. juv. and Micronecta scholtzi, leeches Piscicola geometra, oligochaetes Dero digitata, Stylaria lacustris, Ophidonais serpentina, Limnodrilus sp. juv., and Tubificidae gen. sp. juv., water mites (Hydrachnellae) or larvae of caddisfly Oecetis sp. were especially characteristic. On the other hand, gastropods Gyraulus laevis and Hippeutis complanatus, oligochaetes Nais communis, Enchytraeidae gen. sp., and Aulophorus furcatus, water slaters (Asellus aquaticus), aquatic beetles Cyphon sp. and Enochrus testaceus or some dipteran larvae (Dolichopus sp., Tanypodinae gen. sp., Ceratopogoninae gen. sp. juv.) were more characteristic for the shallow dense interior of reed beds nearer to the shore (Fig. 4).

Based on the first two axes of NMDS on lower (mostly species) and higher (mostly class/order level) invertebrate taxa, the procrustes analysis PROTEST indicated a highly significant concordance between these analyses $\left(m^{2}=0.86\right.$; $p<0.001)$. Thus, the NMDS ordination with higher taxa reflected the investigated gradient similarly to the analysis of lower taxa. All recorded higher taxa were significantly fitted into the NMDS ordination plot (Table 3). Among them, dragonfly, mayfly and caddisfly larvae, leeches and water mites were mostly inhabitants of near the open water zone, while gastropods, crustaceans, dipteran larvae and aquatic beetles were in particular inhabitants of near the shore zone (Figs. 5 and 7). Further, some of the most abundant invertebrates in reed beds, such as water bugs, oligochaetes and chironomid larvae were more equally spatially dispersed in the sampled reed beds, whereas the taxonomic structure of their assemblages changed along the horizontal transect.

We also observed changes in functional feeding group distribution along the horizontal transect, where shredders, grazers, and scrapers (e.g. aquatic snails or naidids) were typical for reed bed areas near the shore, whereas gatherers/collectors (e.g. some oligochaetes or corixids) were more characteristic for reed bed areas near open water. Also parasites (some leeches and water mite nymphs) tended to be more common in these marginal areas near open water (Figs. 6 and 7). Only predators did not express any obvious pattern along the horizontal transect in a reed bed. However, different predators were recorded in areas near open water (leeches, water mites, dragonfly and caddisfly larvae) and near the shore (dytiscids, some dipteran larvae).

Microhabitat preferences of aquatic macroinvertebrates also varied along the investigated horizontal 
Table 2. The results of the PERMANOVA test performed on the Bray-Curtis dissimilarity matrix based on the invertebrate lower taxa (mostly species) abundances along the investigated horizontal transect (sample names according to sampling design).

\begin{tabular}{lcccccc}
\hline & OW1 vs. OW2 & OW1 vs. SH2 & OW1 vs. SH1 & OW2 vs. SH2 & OW2 vs. SH1 & SH2 vs. SH1 \\
\hline Pseudo-F & 0.770 & 2.139 & 4.877 & 0.946 & 3.500 & 1.417 \\
$r^{2}$ & 0.0715 & 0.1762 & 0.3278 & 0.0864 & 0.2592 & 0.1241 \\
$p$-Value & 0.718 & $0.024^{*}$ & $0.003^{* *}$ & 0.476 & $0.008^{* *}$ & 0.196 \\
\hline
\end{tabular}

$* p<0.05 ; * *$ significant difference after Bonferroni correction.

Table 3. Recorded higher taxa and the significance of their linear fit into the two-dimensional NMDS plot.

\begin{tabular}{lll}
\hline & $r^{2}$ & $p$-Value \\
\hline Gastropoda & 0.7257 & $0.001^{* *}$ \\
Oligochaeta & 0.4541 & $0.007^{* *}$ \\
Hirudinida & 0.6556 & $0.001^{* *}$ \\
Crustacea & 0.3790 & $0.008^{* *}$ \\
Hydrachnellae & 0.6653 & $0.001^{* *}$ \\
Ephemeroptera & 0.3636 & $0.010^{* *}$ \\
Odonata & 0.532 & $0.001^{* *}$ \\
Heteroptera & 0.4482 & $0.013^{*}$ \\
Trichoptera & 0.2388 & $0.042^{*}$ \\
Coleoptera & 0.9153 & $0.001^{* *}$ \\
Chironomidae & 0.3431 & $0.013^{*}$ \\
Other Diptera & 0.7588 & $0.001^{* *}$ \\
\hline
\end{tabular}

$* p<0.05 ; * * p<0.01$.

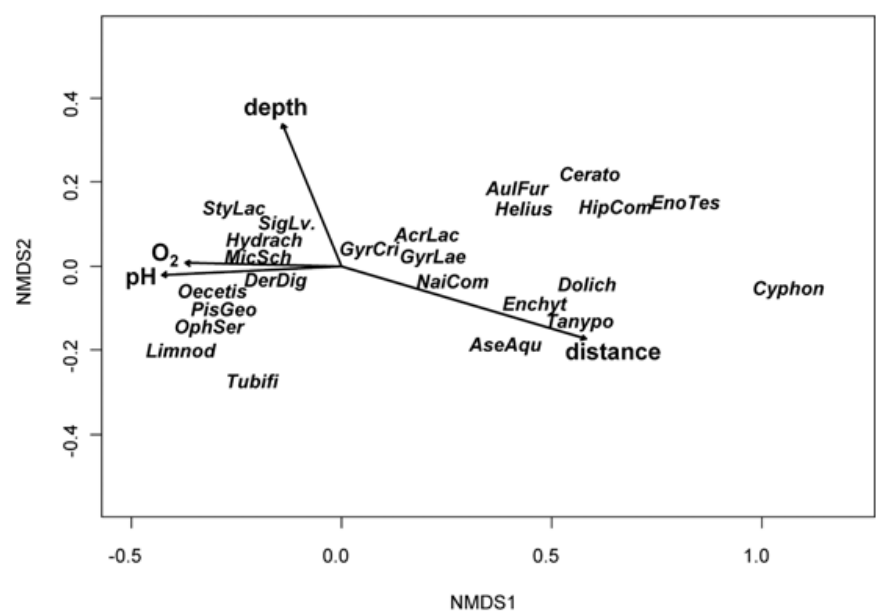

Fig. 4. The NMDS ordination plot in two dimensions performed on lower taxa abundances with the most frequent (with the presence in at least seven samples) significantly-fitted taxa and significantly-fitted vectors of environmental factors. Direction of the distance arrow shows the investigated horizontal transect in the reed bed from open water towards the shore.

transect (Fig. 6). Invertebrates preferring phytal (algae, mosses and macrophytes) and POM (particulate organic matter) microhabitats were recorded to be more abundant closer the shore (e.g. aquatic snails, naidids, some beetles, some chironomid larvae). Conversely, taxa preferring inorganic microhabitats (argyllal, psammal, and akal) and pelal (e.g. tubificids, some aquatic bugs) were most abundant near open water (Fig. 6). The significances of

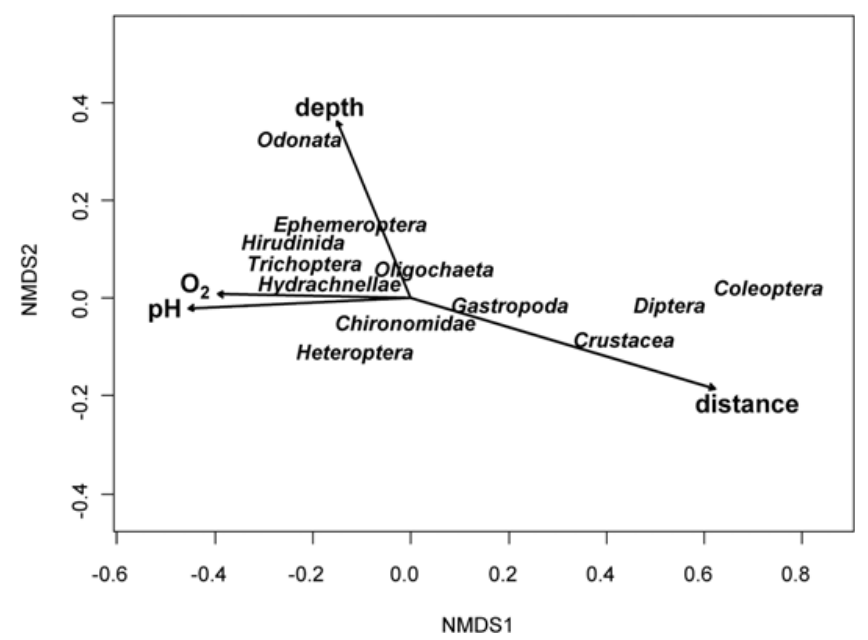

Fig. 5. The NMDS ordination plot in two dimensions with higher invertebrate taxa and significantly-fitted vectors of environmental factors. Direction of the distance arrow shows the main investigated horizontal transect in the reed bed from open water towards the shore.

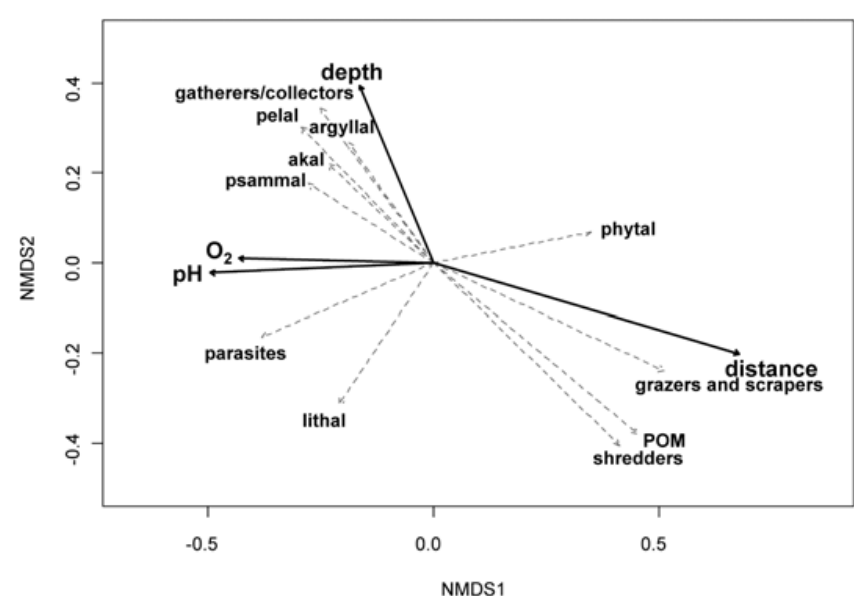

Fig. 6. The NMDS ordination plot in two dimensions performed on lower taxa abundances with significantly-fitted functional feeding groups, microhabitat preferences and environmental factors. Direction of the distance arrow shows the main investigated horizontal transect in the reed bed from open water towards the shore.

functional feeding groups and microhabitat preferences linear fit into the two-dimensional NMDS plot based on invertebrate lower taxa are shown in Table 4. All the important results from this study are summarised in Figure 7. 
Table 4. Functional feeding groups and microhabitat preferences and the significance of their linear fit into the twodimensional NMDS plot based on invertebrate lower taxa.

\begin{tabular}{lcl}
\hline & $r^{2}$ & $p$-Value \\
\hline Grazers and scrapers & 0.7879 & $0.001^{* *}$ \\
Shredders & 0.8286 & $0.001^{* *}$ \\
Gatherers/collectors & 0.4519 & $0.002^{* *}$ \\
Predators & 0.0177 & $0.822 \mathrm{~ns}$ \\
Parasites & 0.4306 & $0.004^{* *}$ \\
\hline Pelal & 0.4396 & $0.002^{* *}$ \\
Argyllal & 0.2642 & $0.048^{*}$ \\
Psammal & 0.2700 & $0.038^{*}$ \\
Akal & 0.2542 & $0.042^{*}$ \\
Lithal & 0.3517 & $0.021^{*}$ \\
Phytal & 0.3144 & $0.015^{*}$ \\
POM & 0.8670 & $0.001^{* *}$ \\
\hline
\end{tabular}

$* p<0.05 ; * * p<0.01 ; \mathrm{ns}=$ not significant.

\section{Discussion}

The taxonomic composition of the littoral assemblage in the Nesyt pond corresponded to other studies targeted on macrophyte bed habitats in lowland eutrophic standing waters (Dvořák, 1970; Kuflikowski, 1970; Dvořák and Imhof, 1998; Menetrey et al., 2008). We found that the taxonomic and functional composition of the macroinvertebrate assemblage varied significantly along the horizontal transect in the reed bed of the lowland pond littoral. Observed differences between close to open water and close to shore reed bed areas could be explained based on gradual changes in environmental conditions from the open water area inwards the reed bed interior (general results are also presented in Fig. 7).

\section{Reed bed areas close to open water}

Macroinvertebrate assemblages inhabiting reed bed areas near open water are affected by the closeness of the open water. Characteristic invertebrates of this marginal zone at the study site were water bugs from the family Corixidae (especially Sigara spp. and Micronecta scholtzi), which are mostly polyphagous active swimmers and which also commonly occur in the deeper open water zone (Wróblewski, 1958; Hufnagel et al., 1999). Near the open water, especially corixid nymphs (Sigara sp. juv.) were found in higher numbers, whereas adults were also more common in the interior of the reed beds. This interesting pattern could be linked with the fact that corixid nymphs are obviously heliophilous (Teyrovský, 1956) and prefer deeper parts of water bodies. Subsequently, during maturity, they move to shallow littoral places (Wróblewski, 1958 for genus Micronecta).

Aquatic insect larvae, such as the larvae of mayflies (Cloeon dipterum, Caenis sp.), dragonflies (Ischnura elegans) and caddisflies (Oecetis sp.) were also abundant in the ecotone between open water and the reed bed at the study site, which can be related to recorded higher

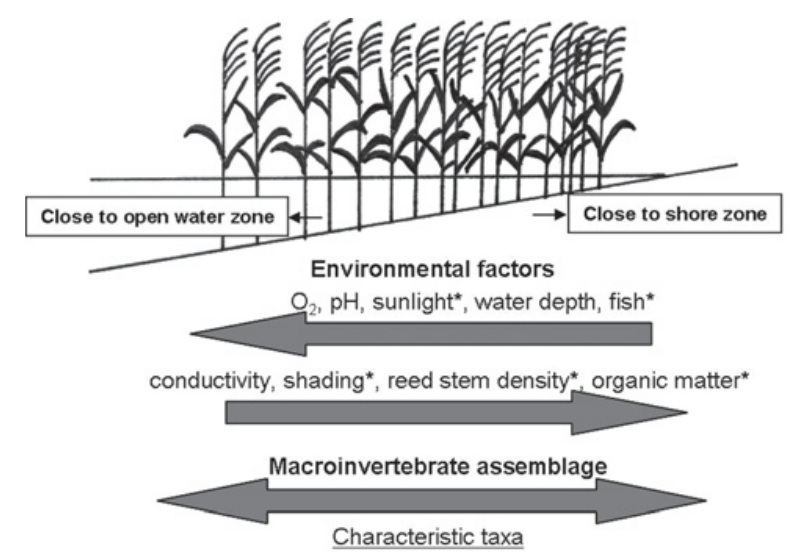

\begin{tabular}{ll}
$\begin{array}{l}\text { Naididae (Stylaria, Dero) } \\
\text { Hirudinida (Piscicola) } \\
\text { Hydrachnellae }\end{array}$ & $\begin{array}{l}\text { Gastropoda (Gyraulus, } \\
\text { Oligochaeta (Nais, Ench } \\
\text { Ephemeroptera (Cloeon, Caenis) } \\
\text { Odonata (Ischnura) } \\
\text { Corixidae (Sigara, Micronecta) } \\
\text { Trichoptera (Oecetis) }\end{array}$ \\
\multicolumn{1}{c}{ Coleoptera (Cyphon, Enctional feeding and } \\
Diptera (Dolichopus, Ta
\end{tabular}

Fig. 7. Changes in environmental factors and macroinvertebrate assemblage composition (characteristic taxa and functional groups) in close to open water and close to shore zones of reed beds in a lowland pond littoral. (Environmental factors according to this study and Dykyjová and Květ, 1978; changes in environmental factors assumed from this publication are indicated (*).)

dissolved oxygen concentration in these reed bed areas. These aquatic larvae breathe exclusively using tracheal gills, which makes them less resistant to poorer oxygen concentrations prevailing inside the reed bed (Dvorák, 1970; Nagell and Fagerström, 1978; Burton et al., 2004; Chapman et al., 2004).

Many taxa which were recorded abundantly in the marginal zones at the study site, such as corixids, naidids or tubificids, are gatherers/collectors feeding mainly on detritus and algae. Similar taxa were also found in exposed compared to protected sites in Great Lake coastal wetlands (Burton et al., 2004). Additionally, some ectoparasites, such as fish leeches (Piscicola geometra) and water mite nymphs, were found to be more common close to the open water. This marginal zone can be a contact zone providing both shelter and easy access to their main hosts, fish and other aquatic vertebrates and aquatic insect larvae (Smith and Oliver, 1986).

Reed bed zones standing near open water can harbour taxonomic and functional groups particularly similar to open littorals without vegetation due to the occurrence of soft sediments (mud) or inorganic substrates, such as sand and gravel. For example, tubificids were more abundant in the marginal areas of reed beds, which is consistent with their preference for soft sediments as a living space (Learner et al., 1978). 


\section{Reed bed areas close to the shore}

In the interior of extensive reed beds, in shallow parts closer to the shore, organic matter accumulation occurs. Therefore, in these parts, many detritovores and invertebrates preferring POM microhabitats, such as some dipteran larvae, water slaters (Asellus aquaticus) or some beetles (mainly larvae of Cyphon sp.) were common at the study site (also Pelikán et al., 1978; James et al., 1988). These taxa can also tolerate low dissolved oxygen conditions (Colon-Gaud et al., 2004), which are incurred by the decomposition processes of large amounts of dead plant tissue and organic detritus there (Zachwieja, 1965; Burton et al., 2004). $\mathrm{CO}_{2}$ production resulting from anaerobic decomposition also decreases the $\mathrm{pH}$ of the water and increases conductivity (Úlehlová and Přibil, 1978), which was recorded at the study site.

Shredders, grazers and scrapers, and invertebrates preferring phytal habitats, such as aquatic snails, naidids and enchytraeids, were especially characteristic for reed bed areas close to the shore at the study site. A higher density of vegetation and increased structural complexity in dense reed beds, which enables rich periphyton overgrowth, represents important feeding sources for these invertebrates (Dvořák and Best, 1982; Diehl and Kornijów, 1998; Heino, 2000). This finding is in concordance with the results of Lodge (1985), Löhlein (1996), Weatherhead and James (2001), and Varga (2003).

One of the most important factors which influenced the distribution of macroinvertebrates in fishpond littorals are fish. Dense macrophyte beds create refuges for macroinvertebrates against fish predation because of their inaccessibility to pond fish (Diehl and Kornijów, 1998; Petr, 2000; Zbikowski and Kobak, 2007). The increase of snail densities in macrophyte beds as a consequence of decreased tench (Tinca tinca) numbers in a Swedish lake was reported by Bronmark and Vermaat (1998). A negative relationship between fish presence and aquatic beetles diversity was also reported (Tate and Hershey, 2003; Hinden et al., 2005). Abundant occurrence of predatory beetles, such as dytiscids, and dipteran larvae, such as the larvae of Tanypodinae, in interiors of dense reed beds at the study site was probably connected with sufficient prey availability and protection against fish in this habitat and was likely related to the structural complexity of aquatic vegetation (Gilinsky, 1984; Nilsson et al., 1994; Heino, 2000; Jayawardana et al., 2006). Generally, predation can play an important role in the horizontal invertebrate distribution in macrophyte beds, since this factor may form a horizontal transition zone in predation, from invertebrate predation inshore to fish predators offshore (Tolonen et al., 2001).

According to our results, we can generalise some patterns of macroinvertebrate spatial distribution along the horizontal transect in reed beds of lowland fishpond littoral (Fig. 7). These patterns probably reflect changes in taxonomic and functional composition of the macroinvertebrate community in connection with changes in some environmental microhabitat conditions (feeding sources, oxygen concentration, fish, substrate characteristics and microhabitat heterogeneity), whereas particular taxa probably respond to changes in some of these conditions. Similar macroinvertebrate distributions to those found in this study were found also by Dvořák (1970) in Glyceria maxima beds, where the shallow outer areas were dominated by snails, some oligochaetes, beetles and dipteran larvae, whereas in areas near open water, other oligochaetes, leeches, phytophilic chironomid larvae, water bugs and large dytiscid beetles were most abundant. On the contrary, we have found this latter group to be more common in samples from the shallow dense reed bed areas.

Changes in the horizontal distribution of the littoral macroinvertebrate community are well known from research on lakes (e.g. Tolonen et al., 2001). Our results indicated that these changes can also be found in the extensive reed beds of lowland fishpond littorals. This finding is very important for pond bioassessment and monitoring. Heterogenous distributions of aquatic invertebrates within extensive reed beds should be considered during the sampling of these habitats, since the selection of keystone mesohabitats will allow for a representative and cost-effective sample of taxonomic richness and functional structure at the site. According to our results, changes in the abundance of some taxa (e.g. Gastropoda, Hirudinida, Coleoptera) equally reflected the investigated spatial gradient in reed beds using higher as well as lower taxa, which can be applicable in rapid bioassessment. On the other hand, for some abundant higher taxa (Oligochaeta, Chironomidae), identification to the lowest taxonomic level is recommended, since their representatives have rather diverse ecological characteristics.

Although extensive dense reed beds are mostly poor in plant species, they represent a specific living space for many aquatic invertebrates. We found higher taxa numbers and also slightly higher abundance of aquatic invertebrates in the interior of reed beds of a lowland fishpond littoral. This suggests that wide reed beds can substitute for small wetland habitats and thus may serve as refuges for many groups of aquatic macroinvertebrates within fishpond ecosystems.

Acknowledgements. We thank Vít Syrovátka and Michal Janáč for help with statistics and Michal Horsák, Petr Pařil, and two anonymous referees for their valuable comments on the manuscript. This study was supported by the Czech Science Foundation-GA $\breve{C R} 524 / 05 /$ H536 and by the Ministry of Education of the Czech Republic (projects no. MSM 0021622416 and CENAKVA CZ.1.05/2.1.00/01.0024).

\section{References}

Anderson M.J., 2001. A new method for non-parametric multivariate analysis of variance. Austral Ecology, 26, 32-46.

AQEM consortium, 2008. ASTERICS: AQEM/STAR Ecological River Classification System, Version 3.1.1, http:// www.fliessgewaesserbewertung.de/download/berechnung/. 
Bazzanti M., Della Bella V. and Grezzi F., 2009. Functional characteristics of macroinvertebrate communities in Mediterranean ponds (Central Italy): Influence of water permanence and mesohabitat type. Ann. Limnol. - Int. J. Lim., 45, 29-39.

Bronmark C. and Vermaat J.E., 1998. Complex fish-snailepiphyton interactions and their effects on submerged freshwater macrophytes. In: Jeppesen E., Søndergaard M., Søndergaard M. and Christoffersen K. (eds.), The structuring role of submerged macrophytes in lakes, Spinger-Verlag, New York, 47-68.

Burton T.M., Uzarski D.G. and Genet J.A., 2004. Invertebrate habitat use in relation to fetch and plant zonation in northern Lake Huron coastal wetlands. Aquat. Ecosyst. Health, 7, 249-267.

Chapman L.J., Schneider K.R., Apodaca C. and Chapman C.A., 2004. Respiratory ecology of macroinvertebrates in a swamp-river system of east Africa. Biotropica, 36, 572-585.

Colon-Gaud J.C., Kelso W.E. and Rutherford D.A., 2004. Spatial distribution of macroinvertebrates inhabiting Hydrilla and coontail beds in the Atchafalaya basin, Louisiana. J. Aquat. Plant Manage., 42, 85-91.

Cox T.F. and Cox M.A.A., 2001. Multidimensional Scaling, Chapman and Hall.

Cyr H. and Downing J.A., 1988. Empirical relationships of phytomacrofaunal abundance to plant biomass and macrophyte bed characteristics. Can. J. Fish Aquat. Sci., 45, 976984.

Diehl S. and Kornijów R., 1998. Influence of submerged macrophytes on trophic interactions among fish and macroinvertebates. In: Jeppesen E., Søndergaard M., Søndergaard M. and Christoffersen K. (eds.), The structuring role of submerged macrophytes in lakes, Springer-Verlag, New York, 24-46.

Dvořák J., 1970. Horizontal zonation of macrovegetation, water properties and macrofauna in a littoral stand of Glyceria aquatica in a pond in South Bohemia. Hydrobiologia, 35, $17-30$.

Dvořák J. and Best E.P.H., 1982. Macro-invertebrate communities associated with macrophytes of Lake Vechten: structural and functional relationships. Hydrobiologia, 95, 115-126.

Dvořák J. and Imhof G., 1998. The role of animals and animal communities in wetlands. In: Westlake D.F., Květ J. and Szczepański A. (eds.), The Production Ecology of Wetlands, The IBP Synthesis, Cambridge University Press, Cambridge, 211-318.

Dykyjová D. and Květ J. (eds.), 1978. Pond Littoral Ecosystems, Structure and Functioning, Ecological Studies, 28, SpringerVerlag, Berlin-Heidelberg-New York, 464 p.

García-Criado F. and Trigal C., 2005. Comparison of several techniques for sampling macroinvertebrates in different habitats of a North Iberian pond. Hydrobiologia, 545, 103-115.

Gilinsky E., 1984. The role of fish predation and spatial heterogeneity in determining benthic community structure. Ecology, 65, 455-468.

Heino J., 2000. Lentic macroinvertebrate assemblage structure along gradients in spatial heterogeneity, habitat size and water chemistry. Hydrobiologia, 418, 229-242.

Hejný S., 1971. The dynamic characteristics of littoral vegetation with respect to changes of water level. Hidrobiologia (Bucuresti), 12, 71-85.
Hejný S. and Husák Š., 1978. Higher Plant Communities. In: Dykyjová D. and Květ J. (eds.), Pond Littoral Ecosystems, Structure and Functioning, Ecological Studies, 28, SpringerVerlag, Berlin-Heidelberg-New York, 23-64.

Hinden H., Oertli B., Menetrey N., Sager L. and Lachavanne J.B., 2005. Alpine pond biodiversity: what are the related environmental variables? Aquatic Conserv.: Mar. Freshw. Ecosyst., 15, 613-624.

Holm S., 1979. A simple sequentially rejective multiple test procedure. Scand. J. Stat., 6, 65-70.

Hufnagel L., Bakonyi G. and Vásárhelyi T., 1999. New approach for habitat characterization based on species lists of aquatic and semiaquatic bugs. Environ. Monit. Assess., 58, 305-316.

James M.R., Weatherhead M.A., Stanger C. and Graynoth E., 1988. Macroinvertebrate distribution in the littoral zone of Lake Coleridge, South Island, New Zealand-effects of habitat stability, wind exposure and macrophytes. N. Z. J. Mar. Freshwat. Res., 32, 287-305.

Jayawardana J.M.C.K., Westbrooke M., Wilson M. and Hurst C., 2006. Macroinvertebrate communities in Phragmites australis (Cav.) Trin. ex Steud. reed beds and open bank habitats in central Victorian streams in Australia. Hydrobiologia, 568, 169-185.

Kuflikowski T., 1970. Fauna in vegetation in carp ponds at Goczalkowice. Acta Hydrobiol., 12, 439-456.

Kuflikowski T., 1977. Macrophytes and phytophilous macrofauna of the pond Zimowy Wielki at Golysz. Acta Hydrobiol., 19, 413-422.

Learner M.A., Lochhead G. and Hughes B.D., 1978. A review of the biology of British Naididae (Oligochaeta) with emphasis on the lotic environment. Freshwater Biol., 8, 357-375.

Lodge D.M., 1985. Macrophyte-gastropod associations: observations and experiments on macrophyte choice by gastropods. Freshwater Biol., 15, 695-708.

Löhlein B., 1996. Seasonal dynamics of aufwuchs Naididae (Oligochaeta) on Phragmites australis in a eutrophic lake. Hydrobiologia, 334, 115-123.

Matlak O., 1963. The appearance of invertebrates on aquatic plants in fish-ponds. Acta Hydrobiol., 5, 1-30.

McArdle B.H. and Anderson M.J., 2001. Fitting multivariate models to community data: A comment on distance-based redundancy analysis. Ecology, 82, 290-297.

Menetrey N., Oertli B., Sartori M. and Wagner A., 2008. Eutrophication: are mayflies (Ephemeroptera) good bioindicators for ponds? Hydrobiologia, 597, 125-135.

Nagell B. and Fagerström T., 1978. Adaptation and resistance to anoxia in Cloeon dipterum (Ephemeroptera) and Nemoura cinerea (Plecoptera). Oikos, 30, 95-99.

Nilsson A.N., Elmberg J. and Sjöberg K., 1994. Abundance and species richness patterns of diving beetles (Coleoptera, Dytiscidae) in Swedish lakes. J. Biogeogr., 21, 197-206.

O’Connor A., Bradish S., Reed T., Moran J., Regan E., Visser M., Gormally M. and Skeffington M.S., 2004. A comparison of the efficacy of pond-net and box sampling methods in turloughs - Irish ephemeral aquatic systems. Hydrobiologia, $524,133-144$.

Oksanen J., Blanchet F.G., Kindt R., Legendre P., O'Hara R.B., Simpson G.L., Solymos P., Stevens M.H.H. and Wagner H., 2010. vegan: Community Ecology Package, R package version 1.17-2, http://CRAN.R-project.org/package=vegan. 
Ondok J.P., 1978. Radiation Climate in Fishpond Littoral Plant Communities. In: Dykyjová D. and Květ J. (eds.), Pond Littoral Ecosystems, Structure and Functioning, Ecological Studies, 28, Springer-Verlag, Berlin-Heidelberg-New York, 113-125.

Pelikán J., Hudec K. and Štastný K., 1978. Animal Populations in Fishpond Littorals. In: Dykyjová D. and Květ J. (eds.), Pond Littoral Ecosystems, Structure and Functioning, Ecological Studies, 28, Springer-Verlag, Berlin-HeidelbergNew York, 74-79.

Peres-Neto P.R. and Jackson D.A., 2001. How well do multivariate data sets match? The advantages of a Procrustean superimposition approach over the Mantel test. Oecologia, 129, 169-178.

Petr T., 2000. Interactions between fish and aquatic macrophytes in inland waters. A review. FAO Fisheries Technical Paper, $n^{\circ} 396$, FAO, Rome.

Pieczyńska E., 1972. Ecology of eulittoral zone of lakes. Ekologia Polska, 20, 637-732.

R Development Core Team, 2009. R: A language and environment for statistical computing. R Foundation for Statistical Computing, Vienna, Austria, http://www.Rproject.org.

Ritterbusch D., 2007. Growth patterns of reed (Phragmites australis): the development of reed stands in carp ponds. Aquacult. Int., 15, 191-199.

Smith I. and Oliver D., 1986. Review of parasitic associations of larval water mites (Acari: Parasitogona: Hydrachnida) with insect hosts. Can. Entomol., 118, 407-472.

Soszka G.J., 1975. Ecological relations between invertebrates and submerged macrophytes in the lake littoral. Ekologia Polska, 23, 393-415.

StatSoft, Inc., 2008. Statistica (data analysis software system), version 8.0, http://www.statsoft.com.

Sychra J. and Adámek Z., 2010. Sampling efficiency of Gerking sampler and sweep net in pond emergent littoral macrophyte beds. Turkish Journal of Fisheries and Aquatic Sciences, 10, 161-167.

Tate A.W. and Hershey A.E., 2003. Selective feeding by larval dytiscids (Coleoptera: Dytiscidae) and effects of fish predation on upper littoral zone macroinvertebrate communities of arctic lakes. Hydrobiologia, 497, 13-23.

Teyrovský V., 1956. Fotopathie larev kleštanek (Corixinae) [Photopathy of the larvae of Corixinae]. Sbornik Vysoké školy pedagogické v Olomouci, Prírodní védy, 2, 147-177.

Tolonen K.T., Hamalainen H., Holopainen I.J. and Karjalainen J., 2001. Influences of habitat type and environmental variables on littoral macroinvertebrates communities in a large lake system. Arch. Hydrobiol., 152, 39-67.

Úlehlová B. and Přibil S., 1978. Water Chemistry in the Fishpond Littorals. In: Dykyjová D. and Květ J. (eds.), Pond Littoral Ecosystems, Structure and Functioning, Ecological Studies, 28, Springer-Verlag, Berlin-HeidelbergNew York, 126-140.

Varga I., 2003. Structure and changes of macroinvertebrate community colonizing decomposing rhizome litter of common reed at Lake Fertö/Neusiedler See (Hungary). Hydrobiologia, 506-509, 413-420.

Weatherhead M.A. and James M.R., 2001. Distribution of macroinvertebrates in relation to physical and biological variables in the littoral zone of nine New Zealand lakes. Hydrobiologia, 462, 115-129.

Wróblewski A., 1958. The Polish species of the genus Micronecta Kirk. (Heteroptera, Corixidae). Ann. Zool. Warszawa, 17, 247-382.

Zachwieja J., 1965. Daily variation of temperature, $\mathrm{O}_{2}, \mathrm{CO}_{2}, \mathrm{pH}$ and alkalinity in the littoral zone of Mamry lake. Polskie Archiwum Hydrobiologii, 13, 5-27.

Zbikowski J. and Kobak J., 2007. Factors influencing taxonomic composition and abundance of macrozoobenthos in extralittoral zone of shallow eutrophic lakes. Hydrobiologia, 584, $145-155$. 